\title{
Granular Cell Tumor of Brachial Plexus Mimicking Nerve Sheath Tumor: A Case Report
}

\author{
Young-Im Kim, Chul-kyu Lee, Ki Hong Cho, Sang-Hyun Kim \\ Department of Neurosurgery, Ajou University School of Medicine, Suwon, Korea
}

Primary tumors of the brachial plexus region are rare and granular cell tumors arising from the brachial plexus region is an extremely rare disease. We present a case of granular cell tumor arising from of the brachial plexus which appeared to be a usual presentation of nerve sheath tumor before the pathological confirmation. We report a granular cell tumor of the brachial plexus with literature review. Total resection is important for good clinical outcome and prognosis in the treatment of granular cell tumor.

Key Words: Granular cell tumor • Brachial plexus

\section{INTRODUCTION}

Primary tumors of the brachial plexus are rare and granular cell tumors of this region is an extremely rare disease ${ }^{3,11,12)}$. It mostly presents as an asymptomatic solitary nodule and can be found in any kind of tissue $e^{2-4,6-10,14,16,17)}$. It is often misdiagnosed because of its usually subtle presentation with histological examination setting the correct diagnosis subsequently. Granular cell tumors behave in a benign fashion, but has a tendency to recur ${ }^{4)}$. Surgical removal with wide margins is the treatment of choice as malignant changes have been reported after long-term follow-up ${ }^{2}$.

We present a case of granular cell tumor arising from brachial plexus which appeared to be a usual presentation of nerve sheath tumor (NST) and review the pertinent literatures.

\section{CASE REPORT}

A 44-year-old woman presented with symptoms of posterior neck pain, left-sided shoulder radiating arm pain, paraesthesia, and persisting ipsilateral arm weakness for 2 years. The family or medical history of patient was unremark- able. Her symptoms

- Received: July 19, 2012 • Revised: September 20, 2012

- Accepted: September 25, 2012

Corresponding Author: Sang Hyun Kim, MD

Department of Neurosurgery, Ajou University School of Medicine, 5

Wonchan-Dong, Youngtong-Gu, Suwon 442-721, Korea

Tel: +82-31-219-5230/5232, Fax: +82-31-219-5238

Email:shkim709@ajou.ac.kr did not improve with conservative treatment. On physical examination, the small round mass was palpable. It was a non-movable and hard consistent mass. There was no definite evidence of skin change around the lesion. On neurological examination, the patient showed grade 3 motor weakness and paresthesia of her left arm mainly on the C7 dermatome. She only showed positive Tinel sign of the left arm. Spurling and Lhemitte signs were negative and there were no abnormal laboratory findings.

Brachial magnetic resonance imaging (MRI) revealed a small and round mass in the C6-7 nerve root area of the left brachial plexus. The size of the tumor mass was $60 \times 25 \times 28 \mathrm{~mm}$. The tumor was relatively well-defined, homogeneous and hyperintense on T2 weighted imaging and hypointense on T1 weighted MRI. The tumor was not enhanced by contrast media (Fig. 1). The initial diagnosis included schwannoma, neurofibroma and lipoma. Soft tissue sarcoma was also considered as well as malignancy could not be completely ruled out.

The patient underwent surgical resection of the mass. Intra-
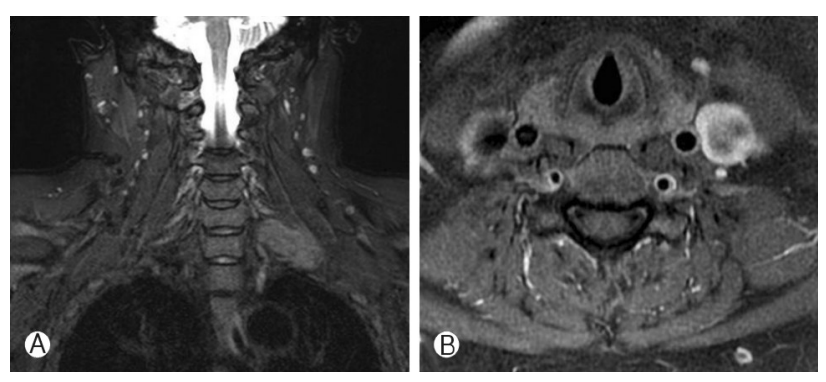

Fig. 1. Preoperative cenvical spine MRI (A: coronal, B: axial) show a small and round mass with cystic enhancement in the C6-7 nerve root area. 


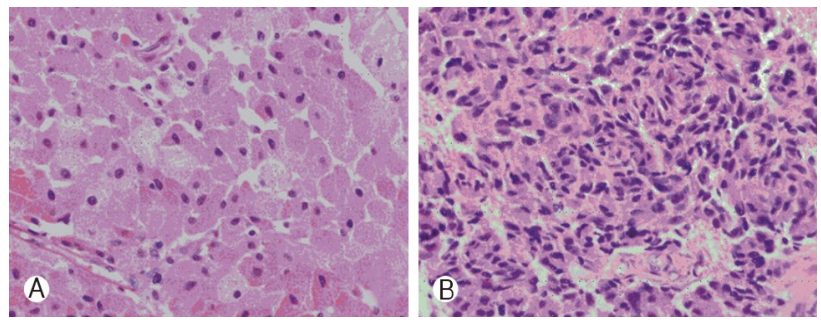

Fig. 2. Granular cell tumor composed of large cells with eosinophilic granular cytoplasm. (A) Recurrent tumor showing increased cellularity and atypia. (B) $(\mathrm{HE} \times 400)$

operatively, the tumor appeared as a smooth globoid mass with relatively solid consistency and clear demarcation. However, gross total resection could not be achieved because the tumor was a fusiform enlargement connecting the lower trunks and roots of the brachial plexus close to the foramen of the C7 vertebra and the upper border of the first rib. The tumor was enucleated and emerged from the nerve roots. Subtotal resection of tumor was performed. Frozen specimen was consistent with a granular cell tumor. Postoperatively, the left shoulder pain got worse compared to the preoperative condition but there was no definite neurologic deterioration.

Histological examination of the specimen showed increased cellularity and pleomorphism. The immunohistochemical assay of the tumor demonstrated positivity for CD68, S-100, PAS and neuron-specific enolase (NSE), suggestive of granular cell tumor (Fig. 2).

Follow-up MRI was done 7 months and 11 months after surgery which showed recurred and rapid growing huge mass at the same area of the left brachial plexus, and the patient received a second operation (Fig. 3). Subtotal resection was performed so that a small portion of tumor mass connecting the lower trunks and roots of the brachial plexus close to the for amen of $\mathrm{C} 7$ vertebra and upper border of the first rib remained.

Histological examination of the second operation specimen showed focally increased cellularity, pleomorphism, high nucleocytoplasmic ratio with increased mitosis of 2/10 HPF. The immunohistochemical stain showed positivity for S-100, negativity for Desmin, and increased MIB-1 that malignant transformation was suggestive. Complete monoplegia developed after the revision surgery and did not improve until the final follow-up. The patient received concurrent chemotherapy and rehabilitation. The patient had no evidence of re-growth until one year after second operation.

\section{DISCUSSION}

The origin of granular cell tumors, known as Abrikossoff's tumor, is uncertain ${ }^{8)}$. It is uncommon with features of usually
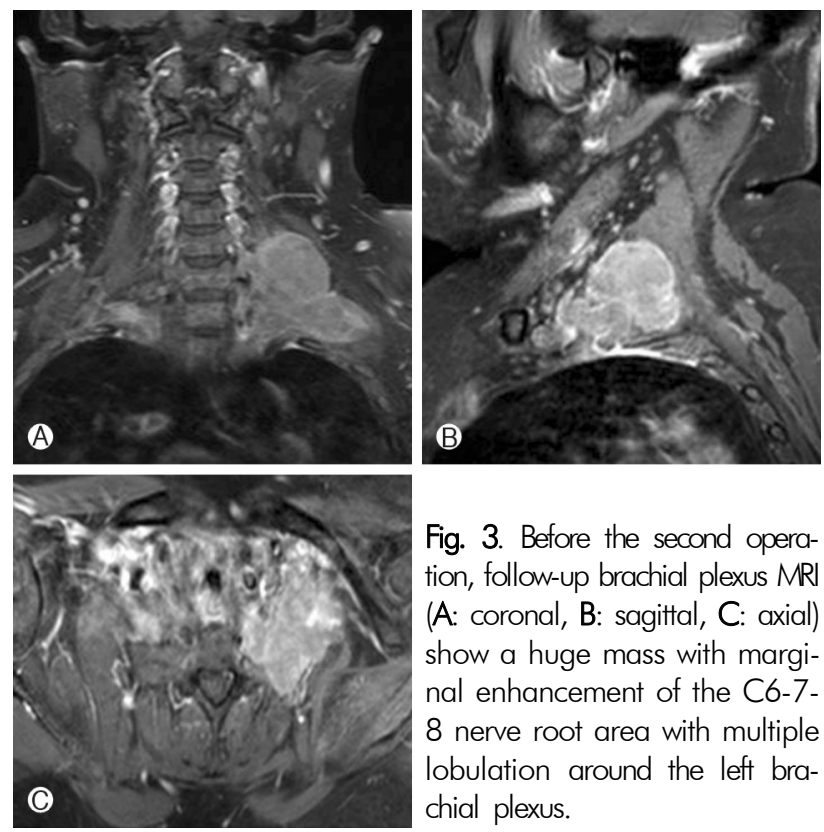

Fig. 3. Before the second operation, follow-up brachial plexus MRI (A: coronal, B: sagittal, C: axial) show a huge mass with marginal enhancement of the C6-78 nerve root area with multiple lobulation around the left brachial plexus.

being small, solitary, benign, and easily recognized by routine light microscopy. Granular cell tumors commonly occurring in the head and neck and other involvement sites such as the breast, gastrointestinal tract, the respiratory tract, thyroid glands, the central nervous system, urinary bladder, female genitalia has been reported ${ }^{7,14,16,17}$. Sometimes, cutaneous and subcutaneous tissues are also involved ${ }^{17}$. Sometimes hyperplasia, paraesthesia or color change of the overlying skin is noted due to chronic irritation of microscopic infiltration of the tumor that requires clinical differential diagnosis from dermatologic diseases". This congenital non-infantile disease has a preponderance for females and blacks, with a peak incidence between the second and sixth decades of life ${ }^{9)}$. There are no clues of image findings that definitely differentiate granular cell tumors from other entities. Therefore, this is the reason why pathological confirmation is much emphasized. The histological examination is the only way to confirm the clinical diagnosis. Microscopically, the granules are usually positive for Periodic acid-Schiff (PAS) and Sudan Black but negative for diastase. Typical granular cell tumors usually show consistent NSE and S-100 positivity ${ }^{9,10)}$.

Treatment of localized granular cell tumors, both benign and malignant, begins with surgical excision. In cases of benign granular cell tumors in which wide local excision takes place, there is 2-8\% recurrence with negative margins and $>20 \%$ recurrence with positive margins ${ }^{13)}$. Ordonez reviewed 41 cases of malignant granular cell tumors in the literature, most of which were treated with wide local excision, and found a $59 \%$ recurrence rate ${ }^{15)}$. The prognosis of the tumor depends on whether its nature is benign or malignant. Granular cell 
tumor is generally regarded benign and benign lesions are known to be safely managed with local excision on clear margins ${ }^{7,9)}$. Radiation and chemotherapy are not advised because of the tumor's high degree of resistance ${ }^{13)}$.

Although most of cases follow a benign course, 1-2\% of granular cell tumors exhibit malignant behavior and behave like high-grade sarcomas with a high rate of metastases and short survival ${ }^{2,4,5,18}$. Tumors typically spread via lymphatic and hematogenous routes to the lungs, liver, and skeletal structures. Metastasis can also become apparent long after surgical excision ${ }^{1}$. Treatment has been largely unsatisfactory, especially for metastatic disease. Moreover, despite the fact that there is no definite evidence of chemotherapy and radiotherapy which statistically significantly improves the outcome, their application in cases of metastatic granular cell tumor is generally accepted $^{4}$.

Due to their benign appearance and rarity, granular cell tumors are often misdiagnosed as nerve sheath tumors or a neurofibroma until histological confirmation. Early recognition as well as differential diagnosis of such tumors in settings of atypical presentation should be taken into careful consideration as well, because granular cell tumor can transform into malignant tumors and be refractory to conventional treatment.

\section{CONCLUSION}

Granular cell tumors are a rare entity of the brachial plexus region and can manifest in many different ways depending on its involvement site. Especially, granular cell tumors of brachial plexus can be misdiagnosed before histologic confirmation because it presents as subtle clinical symptoms, and MRI findings are often similar to other nerve sheath tumors. Surgical treatment is important in that total resection of tumor is the only way to decrease the frequency of recurrence and metastasis because granular cell tumors are refractory to conventional treatment.

\section{REFERENCES}

1. Crawford ES, De Bakey ME: Granular-cell myoblastoma; two unusual cases. Cancer 6:786-789, 1953

2. Crowe D, Ayli EE, Gloster HM, Jr.: A malignant granular cell tumor excised with mohs micrographic surgery. Case Rep Oncol
Med 2012:453-569, 2012

3. Das S, Ganju A, Tiel RL, Kline DG: Tumors of the brachial plexus. Neurosurg Focus 22:E26, 2007

4. Dupuis C, Coard KC: A review of granular cell tumours at the university hospital of the west Indies: 1965-2006. West Indian Med J 58:138-141, 2009

5. Fanburg-Smith JC, Meis-Kindblom JM, Fante R, Kindblom LG: Malignant granular cell tumor of soft tissue: diagnostic criteria and clinicopathologic correlation. Am J Surg Pathol 22:779794, 1998

6. Fernandes BF, Belfort Neto R, Odashiro AN, Pereira PR, Burnier MN, Jr.: Clinical and histopathological features of orbital granular cell tumor: case report. Arq Bras Oftalmol 75:137-139, 2012

7. Finkel G, Lane B: Granular cell variant of neurofibromatosis: ultrastructure of benign and malignant tumors. Hum Pathol 13: 959-963, 1982

8. Honigmann P, Walz A, Bussmann C, Lerf B: Spontaneous bleeding of an abrikossoff's tumor- - a case report. J Cardiothorac Surg 4:57, 2009

9. Khansur T, Balducci L, Tavassoli M: Granular cell tumor. clinical spectrum of the benign and malignant entity. Cancer 60: 220-222, 1987

10. Khansur T, Balducci L, Tavassoli M: Identification of desmosomes in the granular cell tumor. Implications in histologic diagnosis and histogenesis. Am J Surg Pathol 9:898-904, 1985

11. Kim DH, Murovic JA, Tiel RL, Moes G, Kline DG: A series of 146 peripheral non-neural sheath nerve tumors: 30-year experience at louisiana state university health sciences center. J Neurosurg 102:256-266, 2005

12. Kim DH, Murovic JA, Tiel RL, Moes G, Kline DG: A series of 397 peripheral neural sheath tumors: 30 -year experience at louisiana state university health sciences center. J Neurosurg 102:246-255, 2005

13. Lack EE, Worsham GF, Callihan MD, Crawford BE, Klappenbach S, Rowden G, et al: Granular cell tumor: a clinicopathologic study of 110 patients. J Surg Oncol 13:301-316, 1980

14. Nakajima M, Kato H, Muroi $H$, Sugawara A, Tsumuraya $M$, Otsuka K, et al: Esophageal granular cell tumor successfully resected by endoscopic submucosal dissection. Esophagus 8: 203-207, 2011

15. Ordonez NG: Granular cell tumor: a review and update. Adv Anat Pathol 6:186-203, 1999

16. Rose B, Tamvakopoulos GS, Yeung E, Pollock R, Skinner J, Briggs T, et al: Granular cell tumours: a rare entity in the musculoskeletal system. Sarcoma 2009:765-927, 2009

17. Tamborini F, Cherubino M, Scamoni S, Valdatta LA: Granular cell tumor of the toe: a case report. Dermatol Res Pract 2010: 2010

18. Tsuchida T, Okada K, Itoi E, Sato T, Sato K: Intramuscular malignant granular cell tumor. Skeletal Radiol 26:116-121, 1997 